\title{
Comparative Study of Two Systems of Production in Barki Sheep
}

M.M. Mokhtar, H.T. Abdel Bary", A.A. Younis, M.S. Mabrouk" and H. Abdel Aziz

Desert Institute, Mataria and Department of Animal Production, Faculty of Agriculture, $A l$ - Azhar University, Cairo,

Egypt.

\footnotetext{
We hundred and eleven mature fat - tailed Barki ewes of mixed ages were used to examine the relationship between input and output in two systems of production. Fifty four ewes were bred 3 times in 2 years during June, February and October (System A) while 57 were bred once per year during June (System B). Apart from the breeding programme both groups were similarly managed. Dry matter intake (DMI) for ewes and their lambs was estimated up to marketing age in both systems over the experimental period. Weaning took place at 8 weeks of age in system $A$ and at 12 weeks in system B, while marketing of lambs took place at 9 months in both systems.
}

System A significantly exceeded system B by $55.5 \%$ in number of lambs born / ewe joined (2.8 vs. 1.8), 52.9\% in number of lambs weaned / ewe joined (2.6 vs. 1.7 ), 56.3\% in number of lambs marketed / ewe joined (2.5 vs. 1.6), $21.3 \%$ in $\mathrm{kg}$ weaned lambs / ewe joined $(38.8$ vs. 32.0 ) and $43.4 \%$ in $\mathrm{kg}$ marketed lambs / ewe joined ( 92.2 vs. $64.3)$ respectively. The DMI / ewe and its lamb (S) up to marketing a.e were 1246.8 and $963.0 \mathrm{~kg}$ for systems $A$ and $B$, respectively, with an increament of $29.5 \%$ for the former compared to the later system.

Keywords : Barki sheep and Systems of Production.

Sheep are known to be the lowest in efficiency of meat production among different livestock (Owen, 1976). Local Barki sheep has low production rate (Younis and Galal, 1973; Aboul - Naga, 1983) and Low biological efficiency of meat production (Younis et al ., 1984).

Younis (1977) discussed in details different possibilities for increasing sheep productivity in arab countries with special reference to Egyptian conditions. Rebreeding is considered one of the main avenues suggested for increasing productivity and improving production efficiency in local sheep. This is based on the fact that in Egypt ewes exhibit 
oestrus all year round with significant monthly variation (R1 - fouly et al., 1977; Younis, 1977; Aboul - Naga and Aboul - Ela, 1986). Three lambings in 2 years is visible under local conditions (Aboul - Naga, 1983) and could increase efficiency of meat production. Howevr, frequent breeding is also expected to increase feed costs which represent a substantial item of sheep production under local conditions. Therefore, information on the relationship between input and output is needed before recommending such a system. Thus, this paper examines the relationship between input and output in two systems of production ( 3 lambings in 2 years vs. 2 lambings in 2 years) in local Barki sheep.

\section{Miateriais and Methods}

\section{Experimental animals}

One hundred and eleven mature, coarse - wooled, fat - tailed, Barki ewes of mixed ages $(2-6$ years) were used in this study, of those 54 were chosen at random within age to be bred 3 times in 2 years during June, February and October (System A), while the remaining 57 were bred once per year during June (System B).

\section{Management}

Mating period was limited to 34 days in any breeding season. The first breeding season occured in June for both systerns. During mating, ewes within cach system, were divided at random to 3 subgroups of about 20 ewes each and were joined with a fercile Barki ram. Rams were daily rotated among the groups to avoid sire group confounding effects.

Ewes were fed in a group feeding according to their average live body weight and physiological status (NRC, 1975) on berseem hay ( Trifolisem alexandrinum) plus a concentrate mixture $(65 \%$ undecorticated cotton seed cake, $20 \%$ rice polish, $9 \%$ wheat bran, $3 \%$ molases, $2 \%$ limestone and $1 \%$ common sait). In all cases DMI was estimated for all animals over the experimemal period. Fresh water was available for animals twice daily.

Lambing cccured during November, July and March in system A and during November in system B. Lambs bom were ear taged and weighed within 24 hours after lambing. Lambs were kept with their dams during the suckling period up to weaning, which occured at 8 weeks in system A and 12 weeks of age in systern B. Lambs were fed in the pre- weaning stage on their dam's milk plus small amounts of hay and concentrates, which were offered to their dams. After weaning, lambs were grouped and fed on the same concentrate mixture plus berseem hay according to their body weight (NRC, 1975) up to marketing, which took place at 9 months of age for all lambs regardless of system.

Lambs were weighed biwockily from birth to weaning and at monthly intervals thereafter (weanirg to marimeting ; to low acawest $50 \mathrm{~g}$.

Egypt.J. Anim. Prod, 22, No. 1 (1991) 


\section{Data recorded}

Dry matter intake was estimated for both ewes and their lambs in both systems over the experimental period. Feed samples were taken biweekly for DM determination. All reproductive and productive traits were measured and recorded for ewes in each season and system, and included conception rate, lambing rate, lambing percentage, average litter size, birth weight, weaning weight, marketing weight, total weight of lambs bom, weaned and marketed and daily gain (from birth to weaning and from weaning to marketing).

\section{Statistical analysis}

The least squares method was used for analysing the data of all productive triats. For number of lambs born, weaned and marketed the model of analysis included age of dam and system. Sex was excluded in that model because sex ratio did not differ significantly among both systems. However, for birth, weaning and marketing weights the model included system, age of dam, sex of lamb and season within each system.

The analysis was carried out udilizing Harvey's Mixed Model Programm (1977).

The models were as follows :

1. $\mathrm{Yijk}_{\mathrm{ijk}}=\mathrm{U}+\mathrm{Ai}+\mathrm{Sj}+$ e eijk

where

$Y_{\mathrm{ijk}}=$ number of lambs.

$\mathrm{U}=$ general mean.

$\mathrm{Ai}=$ an effect due to age of dam.

$\mathrm{Sj}=$ an effect due to system of breeding.

eijk $=$ randorn error.

2. $Y \mathrm{ijkim}=\mathrm{U}+\mathrm{Ai}+\mathrm{Sj}+\mathrm{Xk}+\mathrm{O} j \mathrm{j}+$ eijkim

where

Yijkim $=$ weights of lambs.

$\mathrm{U}=$ general mean.

$\mathrm{Ai}=$ an effect due to age of dam.

$\mathrm{Sj}=$ an effect due to system of breeding.

$\mathrm{Xk}=$ an effect due to sex of lamb.

$\mathrm{O}_{\mathrm{jl}}=$ season within system.

eijkim $=$ random ernor

However, traits of discontinuous nature were analysed by Chi - square according to Snedecor and Cochran, (1970).

\section{Resulits and Discussion}

\section{Livebody weight changes of ewes}

Average live body weight of ewes at the start of the experiment was 41.9 and $32.2 \mathrm{~kg}$ in systems A and B, respectively. Ewes gained on the average 9.6 and $9.7 \mathrm{~kg}$ from mat- 
ing to the end of pregnancy for Systems A and B, respectively. These values indicated that ewes on both systems were well fed and managed. It indicates as well that rebreeding had no deleterious effect on ewe condition, provided proper feeding and management were practiced.

\section{Reproductive and productive performance of ewes}

Average length of oestrous cycle (single cycles osily) was 17.8 and 14.5 days for ewes on systems A and B, respectively, with an overall mean of 16.1 days (Table 1). This estimate lies within the normal range of 14.2 to 17.3 days reported by Badawy $e t$ al . (1973) and Younis et al . (1984) for the same breed.

TABLE 1. Reproductive and productve performance of ewes ha two systems of production.

\begin{tabular}{|c|c|c|c|c|c|c|c|}
\hline \multirow[b]{2}{*}{ Traits } & \multicolumn{3}{|c|}{ System A } & \multirow{2}{*}{$\begin{array}{c}\text { Over } \\
\text { all }\end{array}$} & \multicolumn{2}{|c|}{ System B } & \multirow{2}{*}{$\begin{array}{c}\text { Over } \\
\text { all }\end{array}$} \\
\hline & $S A_{\text {I }}$ & $S A_{2}$ & $\mathrm{SA}_{3}$ & & $\$ B_{1}$ & $\mathrm{SB}_{2}$ & \\
\hline No. of ewes joined & 54.00 & 54.00 & 54,00 & 162.00 & 57.00 & 57 & 114 \\
\hline Average oestrous cycle length (days) & 18.20 & 17.50 & 17.50 & 17.80 & 16.00 & 12.80 & 14.5 \\
\hline $\begin{array}{l}\text { No. of ewes concieved (Lambed + } \\
\text { Aborated) }\end{array}$ & 46.00 & 46.00 & 50.00 & 142.00 & 48.00 & 50.00 & 98 \\
\hline No. of ewes lambed & 44.00 & 46.00 & 50.00 & 140.00 & 46.00 & 50.00 & 96 \\
\hline Conception rate (\%) & 85.20 & 85.20 & 92.50 & 87.60 & 84.20 & 87.70 & 85.9 \\
\hline Lambing rate (\%) & 83.30 & 85.20 & 92.50 & 87.00 & 80.70 & 87.70 & 84.2 \\
\hline Lambing percentage & 87.00 & 87.001 & 107.00 & 93.70 & 87.70 & 94.70 & 91.2 \\
\hline Average litter size & 1.07 & 1.02 & 1.16 & 1.08 & 1.04 & 1.08 & 1.06 \\
\hline No. of lambs bom & 47.00 & 47.00 & 58.00 & 152.00 & 50.00 & 54.00 & 104 \\
\hline No. of lambs weaned & 44.00 & 45.00 & 54.00 & 14300 & 46.00 & 49.00 & 95 \\
\hline No. of lambs marketed & 42.00 & 43.00 & 49.00 & 134.00 & 44.00 & 48.00 & 92 \\
\hline \multicolumn{8}{|l|}{ Mortality of lambs } \\
\hline from birth to weaning & 6.40 & 4.30 & 6.90 & 5.90 & 8.00 & 9.30 & 8.7 \\
\hline from weaning to marketing & 4.60 & 4.50 & 9.30 & 6.10 & 8.30 & 2.00 & 5.2 \\
\hline $\begin{array}{l}\text { Total weight of lambs bom / ewe } \\
\text { joined }\end{array}$ & 3.20 & 3.50 & 3.80 & 10.50 & 3.30 & 3.40 & 6.7 \\
\hline $\begin{array}{l}\text { Total weight of lambs weaned / ewe } \\
\text { joined }\end{array}$ & 11.90 & 12.80 & 14.10 & 38.80 & 16.00 & 16.00 & 32.0 \\
\hline $\begin{array}{l}\text { Total weight of lambs marketed / ewe } \\
\text { joined }\end{array}$ & 28.50 & 29.40 & 34.20 & 92.20 & 31.20 & 33.10 & 64.3 \\
\hline
\end{tabular}

System A, 3 lambing in 2 years

System B, 2 lambings in 2 years

$\mathrm{SA}_{1}$, June, 1984

$\mathrm{SA}_{2}$, February, 1985

$\mathrm{SA}_{3}$, October, 1985

$\mathrm{SB}_{1}$, June 1984

$\mathrm{SB}_{2}$, June, 1985

Egypt. J. Anim. Prod., 28, No. 1 (1991) 
Conception rate ranged from 85.2 to $92.5 \%$ for ewes on system A with an average of $87.6 \%$ and from $84.2-87.7 \%$ with an average of $85.5 \%$ for those on system B, differences being nonsignificant. Within system $\mathrm{A}$, ewes mated in October had a higher conception rate compared to those mated in either June or February, which agrees with Aboul - Naga e? al. (1991) who found that there was a significant variation in the breeding activity at different mating sessons.

Dzakuma et al . (1982) found that in five combinations of Finnsheep, Dorset and Rambouillet, fertility of ewes was reduced during May - June breeding ( $47.8 \%)$ compared to January - february breeding (91.8\%) and September - October breeding (90.6).

Lambing rate expressed as the number of ewes lambing per ewe bred was 87.0 and 84.2 for systems $A$ and $B$, respectively, differences being nonsignificant. However, these values lie within the normal range ( 84.6 to $92.0 \%$ ) of lambing rate for Barki sheep reported previousiy by Aboul - Naga and Aboul - Ela (1986).

The average litter size was 1.08 and 1.06 for ewes on systems A and B, respectively, being higher than previous estimates reported for the same breed (Younis et al., 1984), System $A$ excecded system $B$ significantly (Tables 1 \& 2) by $55.5 \%$ in number of lambs born per ewe joined ( $2.8 \mathrm{vs}$. 1.8). $52.9 \%$ in number of lambs weaned per ewe joined ( 2.6 vs. 1.7$)$ and $56.3 \%$ in number of lambs marketad per ewe joined ( 2.5 vs. 1.6). Aboul Naga (1983) working on Ossimi, Rahmani and Barki sheep for 18 successive crops, found that the number of lambs weaned per ewe joined for system $A$ was $0.71,0.80$ and 0.66 , respectively. The corresponding values for system $\mathrm{B}$ were $0.95,1.06$ and 0.92 . Similar results were obtained by Goot and Maijala, (1977) in a twice - yearly lambing systern The number of lambs bom per ewe were 1.52 and 4.03 for ewes lambed once within a calender year and lambed twice, respectively.

TABLE 2 . Lesst saymes mearos and standired errors for numbers of lambs born, weaned, mariseted per ewe joined.

\begin{tabular}{|c|c|c|c|}
\hline $\begin{array}{l}\text { Source of } \\
\text { variation }\end{array}$ & $\begin{array}{l}\text { Namber of /smbs } \\
\text { borm / ewe }\end{array}$ & $\begin{array}{l}\text { Number of lombs } \\
\text { wenned / ewe }\end{array}$ & $\begin{array}{l}\text { Number of lambs } \\
\text { marketed / ewe }\end{array}$ \\
\hline $\begin{array}{l}\text { System } \\
\text { A } \\
\text { B }\end{array}$ & $\begin{array}{l}1.95 \pm 0.025 * \\
1.67 \pm 0.018\end{array}$ & $\begin{array}{l}1.90 \pm 0.02 A \% \\
1.62 \pm 0.025\end{array}$ & $\begin{array}{l}1.86^{*} \pm 0.027 \\
1.61 \pm 0.026\end{array}$ \\
\hline $\begin{array}{l}\text { Age of dam } \\
2-3 \mathrm{yrs} \\
3-4 \mathrm{yrs} \\
>4 \mathrm{yrs}\end{array}$ & $\begin{array}{l}1.78 \pm 0.042 \\
1.83 \pm 0.027 \\
1.82 \pm 0.025\end{array}$ & $\begin{array}{l}1.74 \pm 0.041 \\
1.78 \pm 0.026 \\
1.76 \pm 0.025\end{array}$ & $\begin{array}{l}1.71 \pm 0.045 \\
1.76 \pm 0.028 \\
1.73 \pm 0.027\end{array}$ \\
\hline
\end{tabular}

$* \mathrm{P}<0.05$

System A, 3 Lambing in 2 years

System B, 2 Lambing in 2 years

Egypt.J. Anim. Prod., 28, No. 1 (1991) 
System of production had a highly significant effect on the total weight of lambs born, weaned and marketed per ewe joined (Table 1). System A exceeded system B by $21.3 \%$ of total weight of lambs weaned $(38.8 \mathrm{vs} .32 .0 \mathrm{~kg})$ and $43.3 \%$ of lambs marketed per ewe joined ( 92.2 vs. $64.3 \mathrm{~kg}$ ).

Average birth weight was 3.86 and $3.83 \mathrm{~kg}$ for lambs on systems $\mathrm{A}$ and $\mathrm{B}$, respectively, with an overall mean of $3.84 \mathrm{~kg}$ (Table 3). Previous estimates in the literature for the same breed ranged from 2.34 io $3.93 \mathrm{~kg}$ (Fahmy et al ., 1969).

TABLE 3. Least squares meang and stsmaiared errors for lambs weights (kg) at direrent ages.

\begin{tabular}{|c|c|c|c|c|}
\hline $\begin{array}{l}\text { Source of } \\
\text { variation }\end{array}$ & $\begin{array}{l}\text { Birth } \\
\text { welght }\end{array}$ & $\begin{array}{l}\text { Weight at } \\
16 \text { weeks }\end{array}$ & $\begin{array}{l}\text { Welght at } \\
24 \text { weeks }\end{array}$ & $\begin{array}{c}\text { Marketing weight } \\
36 \text { weeks }\end{array}$ \\
\hline \multicolumn{5}{|l|}{ System } \\
\hline A & $3.86 \pm 0.07$ & $20.47 \pm 0.55$ & $25.80 \pm 0.81 *$ & $33.15 \pm 1.08 *$ \\
\hline B & $3.83 \pm 0.08$ & $21.11 \pm 0.62$ & $27.53 \pm 0.91$ & $36.99 \pm 1.21$ \\
\hline \multicolumn{5}{|c|}{ Senson / system } \\
\hline $\mathrm{SA}_{1}$ & $3.82 \pm 0.13$ & $21.26 \pm 0.96$ & $26.31 \pm 1.41$ & $32.79 \pm 1.88$ \\
\hline $\mathrm{SA}_{2}$ & $4.01 \pm 0.11$ & $20.49 \pm 0.84$ & $25.37 \pm 1.23$ & $31.98 \pm 1.64$ \\
\hline $\mathrm{SA}_{3}$ & $3.7 .4 \pm 0.12$ & $19.65 \pm 0.87$ & $25.73 \pm 1.27$ & $34.69 \pm 1.70$ \\
\hline $\mathrm{sB}_{1}$ & $3.92 \pm 0.12$ & $21.84 \pm 0.41$ & $27.16 \pm 1.33$ & $37.11 \pm 1.78$ \\
\hline $\mathrm{SB}_{2}$ & $3.74 \pm 0.11$ & $20.37 \pm 0.81$ & $27.16 \pm 1.18$ & $36.99 \pm 1.21$ \\
\hline \multicolumn{5}{|l|}{ Sex of lambs } \\
\hline Male & $3.86 \pm 0.08$ & $21.38 \div 0.60^{\star}$ & $27.98 \pm 0.39$ & $36.92 \pm 1.19 \%$ \\
\hline Female & $3.79 \pm 0.08$ & $19.7 \pm 0.60$ & $24.74 \pm 0.85$ & $32.46 \pm 1.13$ \\
\hline \multicolumn{5}{|l|}{ Age of dam } \\
\hline $2-3 y r s$ & $3.57 \pm 0.13^{200}$ & $20.88 \pm 0.99$ & $26.04 \pm 1.46$ & $33.79 \pm 1.95$ \\
\hline $3-4 y r s$ & $3.89 \pm 0.11$ & $20.01 \pm 0.82$ & $26.55 \pm 1.20$ & $35.10 \pm 1.60$ \\
\hline$>4 \mathrm{yrs}$ & $4.03 \pm 0.068$ & $20.74+0.74$ & $26.51 \pm 0.69$ & $35.18 \pm 0.92$ \\
\hline
\end{tabular}

\begin{tabular}{|c|c|c|}
\hline$* P<0.05 * P<0.01$ & $\mathrm{SA}_{2}$ & , Felkurary, 1983 \\
\hline System A, 3 lambing in 2 yers & $\mathrm{SA}_{3}$ & - October, 1985 \\
\hline System B, 2 lambing in 2 yeas & $S B_{1}$ & , Jume, 1984 \\
\hline $\mathrm{SA}_{1}$, June, 1984 & $3 B_{2}^{1}$ & , June, 1985 \\
\hline
\end{tabular}

Season of lanbing had no significant effect on lismb birth weight while age of darn significantly affected the serme trait. There is a tendency of increase in binth weight of lanbs with the adivancernent of age of dam; such diend may be due so chinges which occur in the uterine enviromment. Younis es at . (1984) chserved the same, trend and found that the significsnt effect of age of dant on birth weight disappeared at later stage. Sex of lamb had no significant effect on birh weight with bin overall meanin of 3.79 and 3.87 for females and males, rezpectively. However, sex of lanb sifteres significantly subse-

Egypt. J. Anims. Prod, 23, No. 1 (1991) 
quent weights in favour of male ones (at 16,24 and 36 weeks of age). This is in agreement with Sidwell and Miller (1971) and Ragab et al . (1978).

Average weight of lambs at 16 weeks was 20.5 and $21.1 \mathrm{~kg}$ for lambs of systems A and $\mathrm{B}$, respectively. Systern and season of lambing had no significant effect on weight of lambs at 16 and 24 weeiss of age, which agrees with the findings of Kassab and Karam (1961).

Marketing weight was 33.2 and $37.0 \mathrm{~kg}$ for immbs of systems $\mathrm{A}$ and $\mathrm{B}$, respectively, such difference being significant. This is expected since lambs of system B had more chance with their dams than those of system A. Male lambs were significantly heavier than females at marketing by $4.4 \mathrm{~kg}$ (36.9 vs. $32.5 \mathrm{~kg})$. However, season of lambing had no significant effect on the same trait.

Mortality rate of lambs bom in systern A was 5.9 and $6.1 \%$ from birth to weaning (8 weeks old), and weaning to maketing, respectively (Table 1). Corresponding values for system $\mathrm{B}$ were 8.7 , and $5.2 \%$, differences between systems being not significant $\left(\mathrm{X}^{2}=\right.$ 0.72 and 1.14). With the exception of summer bom lambs (SA3) mortality rate in this study was of reasonable magnitude. This may be due to the high mothering ability of Barki ewes companed to other breeds (Galal et al ., 1972). However, resuits of the present study show that under practical farm conditions proper management and feeding could reduce lamb losses when lambs are kept with their dams up to at least 8 weeks of age.

\section{Conclusion}

Studies on the output of local sheep in relation to the input are very limited. Under local conditions feed costs represent the major part of input while lamb production represents the main source of cutput.

In the present study, the total DMI by the ewe and its lamb up to marketing was 1246.8 and $963.0 \mathrm{~kg}$ for systems $A$ and $B$, respectively. This means that animals on system A consumed $29.5 \%$ more DM then those on system B over the experimental period. On the other hand system A significantly exceoded system B by $43.4 \%$ in $\mathrm{kg}$ martreted lambs per ewe joined (92.2 vs. $64.3 \mathrm{~kg})$. Meanwhile, labour cost increase by $25 \%$ in system A compared to system B.

Accordingly accelerating lamb production by using a system of 3 lambings in 2 years caused an increament in DMI by $29.5 \%$, while resulting in $43.4 \%$ increament in $\mathrm{kg}$ marketed lambs per ewe joined compared to the conventional systern of 2 lambings in 2 years. In view of the fact that the value of unit weight of feed is far below that of live body weight of lsmbs, accelerated lambing is considered an effective method of improving efficiency of meat production in local sheep. 


\section{Acknowledgements}

We recorded our gratitude to Dr. E.S.E. Galal, Professor of Animal Breeding and Dr. H. Mansour, Assistant Professor of Animal Breeding, Animal Production Department, Ain Shams University for help in Statistical analysis.

\section{References}

Aboul - Naga, A.M. (1983) Lamb crop every eight months from subtropical fat - tailed sheep. The Vth world conference on Animal Production August 14 - 19. Japanese Society of Zootechnical Science, Tokyo, Japan Vol , $2: 147$.

Aboul - Naga, A.M. and Aboul - Ella, M.B. (1986) Performance of subtropical Egyptian sheep breeds, European breads and their crosses with Egyptian sheep breeds. World Review of Anim. Prod ., $23: 75$.

Aboul - Naga, A.M. Aboui - Ela, M.B., Mamsour;, H. and Almalhdy, H. (1991) Breeding acivity of two suberopicai Egyptian shoep broeds under acceieratod lambing system. Small Ruminant Research $4: 285$.

Badawy, A.A., El - Bashary, A.S. and Mohser, N.K.M. (1973) A study of sexual behaviour of female Barki sheep. Alex. J. of Agric., Res., 21: 1 .

Dzakums, J.M.s Stritake, D J. and Whilterana, J.V. (1982) Fertility and prolificacy of crossbred ewes under two cycles of scceirated lambing. J. Anim. Sci. S4 : 213.

El - Fouly, M., Shafle, M.M., Abdel - Azlz, A.S. and Kandeel, S. (1977) Seasonal variaticn in oestrous activity in Orsini and Rahmsmi ewes. Egypt. J. Anims. Prod. $17: 75$.

Fahmy, M.H., Gala, E.S.E., Ghamem, Y.S. and El - Kahlin, S.S. (1969) Crossbreeding sheep under semierid conditions. Arims. Prod., 118 : 351.

Galal, L.S.E., Seoudy, A.Mor Younds, A.A. and Khishilin, E.S. (1972) Feetlot performance and carcass characteristics of yesrling Barki sheep and their corosses with Merino. Alex. J. of Agric. Res., $19: 115$.

Goot, H. and Mallala, K. (1977) Reproductive performance at first lambing and in twice -yearly lambing in a flook of Finnsh Landrece sheep in Firland. J. Anim. Prod. 25 : 319.

Harvey, W.R., (1977) User's guide for LSML 76 Mixed Model Least - Squares and Maximum Likelihood Computer Progranm. The Ohio State University, Columbus (Mimco).

Kassab, S.A. and Karam, H.A. (1961) Effect of some environmental fectors on body and fleace weight of Barki sheep. J.Anin. Prod. U.A.R. 1 : 149.

N.R.C. (1975) National Academy of Science - National Rescarch Council. Nurrient Reguirements of Sheep, N. S. Pub., 1975, Washington, D.C.

Egypt. J. Anim. Prod., 28, No. 1 (1991) 
Owen, J.B. (1976) Sheep Production. Ed. by Bailliere, Tindall, A division of Cassel \& Collier Macmillan Publishers Lid.

Ragab, M.T., Sharafedhe, M.A. and Budawy, F.S (1978) Factors affecting body weight and carcass yield of flock of Finish Merino sheep under subtropical conditions. Egypt. J. Anim.

Prod. 18 (2) 187.

Sidwell, G.M. and Miller, L.R. (1971) Production in some pure breeds of sheep and their crosses. 1) Reproductive efficiency in ewes. $J$. Anim. Sci., $32: 1024$.

Snedecor, G.W. \& Cochran, W.CE. (1970) Sratisical Methods. 5 th ed. Iowa State University, Ames. Iowa.

Younis, A.A. (1977) Incressing ewe ferciity in Arab countries. World. Review of Anim. Prod., 13: 361.

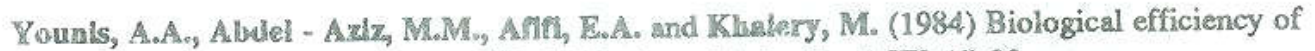
meat production in Briki sheep. World. Review of Anim. Prod. XX, (4) 32.

Youmis, A.A. and Galal, E.S.IE. (1973) A study of factors affecting incidence of lambing in the yearling ewe. Egypt. J. Anim. Prod., $13(1): 9$.

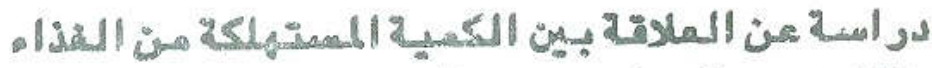

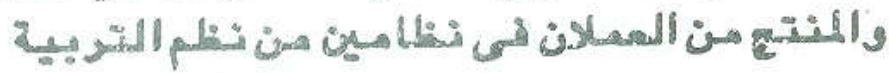

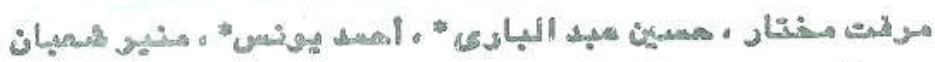

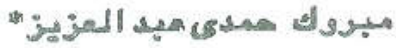

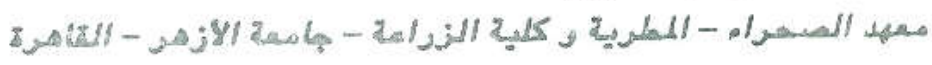

$$
\begin{aligned}
& \text { - inas }
\end{aligned}
$$

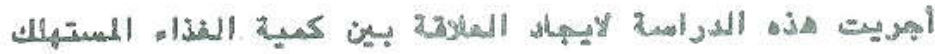

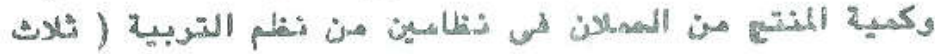

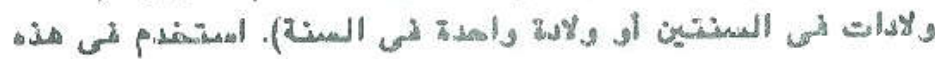

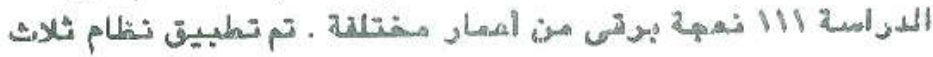

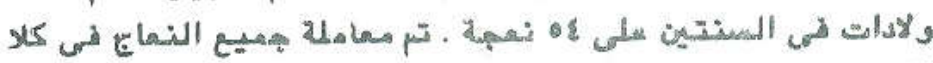

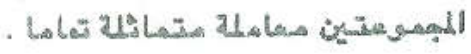

Egypt. I. Anim. Prod., 28, No. 1 (1991) 


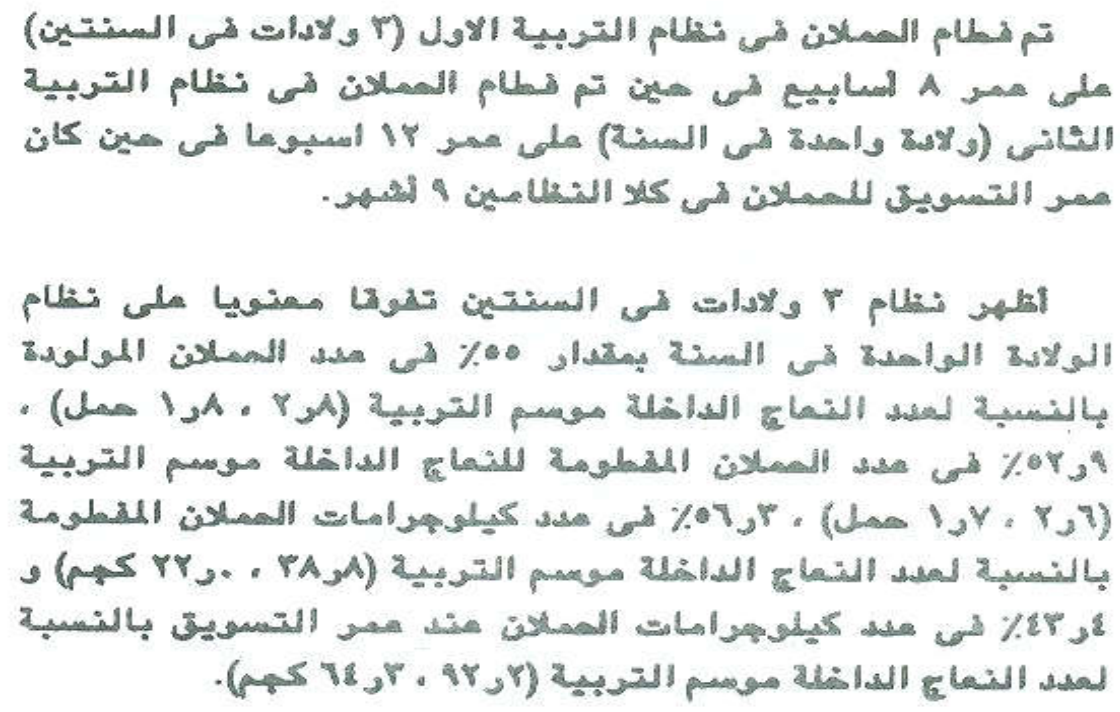

Esypt. J. Aniom Prod., 28, No.1 (1991) 